- współczesne media i eksperyment chemiczny. Nowoczesne media tworzą szansę znacznie głębszego wnikania w poznawaną rzeczywistość oraz przybliżania jej uczniom i studentom;

- strategie uczenia się studentów fizjoterapii Uniwersytetu Medycznego we Wrocławiu;

- interaktywny system pomocy w multimedialnym module edukacyjnym;

- specyficzne formy reedukacji;

- komputer w edukacji przedszkolnej;

- media w aspekcie pedagogicznej funkcji czasu wolnego ludzi dorosłych;

- wikimedia w edukacji;

- edukacja medialna w perspektywie ekologicznej;

- kanadyjski model immersyjnej edukacji medialnej;

- projektowanie graficzne a proces czytania i tworzenia wizualnych znaczeń;

- eyetrackingowe badania prezentacji multimedialnych konstruowanych dla wspomagania edukacji wczesnoszkolnej;

- platforma lot4eng.com jako narzędzie wspierające kształcenie ustawiczne;

- działania profilaktyczne wobec zagrożeń medialnych.

Wymienione opracowania wiele wnoszą do metodyki wykorzystania mediów w procesie edukacyjnym. Autorzy poszczególnych opracowań szeroko wykorzystali najnowszą literaturę krajową i zagraniczną dotyczącą omawianej problematyki. Wykazali też wiele inwencji twórczej $\mathrm{w}$ zakresie zastosowania mediów zarówno w pracy szkolnej, jak również w życiu.

Biorąc pod uwagę niezaprzeczalne walory teoretyczne i praktyczne opracowań zawartych w opiniowanej pracy, uważam, iż jej treść jest szczególnie przydatna dla studentów kierunków nauczycielskich, a także dla nauczycieli praktyków.

\title{
ROBERT SZYMIEC
}

Wyższa Szkoła Języków Obcych

w Poznaniu

L. V a n Li er, The Ecology and Semiotics of Language Learning. A sociocultural perspective, Kluwer Academic Publishers, Boston-Dordrecht-New York-London 2004, ss. 252

\section{DLACZEGO TA KSIĄŻKA JEST WAŻNA}

Zdecydowaliśmy się przedstawić The Ecology and Semiotics of Language Learning z kilku powodów. Nie tylko dlatego, że jest to przełomowa pozycja proponująca zupełnie nowatorskie rozumienie języka jako fenomenu samego w sobie, ale również ze względu na to, że prezentuje wynikające z niej praktyczne konsekwencje tej zmiany dla nauczania języków w szkole.

Drugą przyczyną jest zbieżność prezentowanych tutaj koncepcji z bliskimi nam zagadnieniami związanymi z pojęciami immersji i nauczania responsywnego, prezentowanymi już na łamach „Neodidagmaty”. Recenzja ta nie powstała więc jako przypadkowe i standardowe przedstawienie równie przypadkowo wybranej pozycji. Jest ona 
efektem przemyśleń i dyskusji nad zawartymi w niej koncepcjami, które w nieoczekiwany sposób okazują się zbieżne z naszą filozofią języka, jego użycia i nauczania.

W zawartości merytorycznej książki można wyznaczyć co najmniej dwie linie podziału, które stwarzają cztery obszary tematyczne: ekologia oraz semiotyka w rozumieniu języka i procesów poznawczych, a następnie każde z tych dwóch pojęć w odniesieniu do języka jest przetransponowane na codzienną praktykę w nauczaniu. Tym samym autor uniknął błędu przeintelektualizowania części teoretycznej i ograniczenia się do niej - co z pewnością zmniejszyłoby znacznie docelowy krąg odbiorców. Jednocześnie ścisłe powiązanie tych nowatorskich zagadnień ze stroną praktyczną jest co najmniej dostatecznie uzasadnione po to, aby każdy nauczyciel chcący je wprowadzić do swojej codziennej praktyki, mógł to zrobić z przekonaniem o ich teoretycznym uzasadnieniu.

Wreszcie, zważywszy na jednolitość i zorientowanie na testy niepodzielnie obecnie panujące $\mathrm{w}$ szkołach kierowanych przez kuratorium, chcielibyśmy wskazać osobom podejmującym decyzje $\mathrm{w}$ tej mierze fakt istnienia nowoczesnych koncepcji nauczania, które nie bazują na powielanych ad noseaum programach nauczania i proponują zupełnie nową jakość edukacji. Jednocześnie z realizacją takich przestarzałych merytorycznie programów odmawia się w szkolnej rzeczywistości miejsca na zaistnienie żywego języka, zbieżnego z zainteresowaniami uczniów, gdyż często takie przekazy nie są zgodne z aktualnymi wskaźnikami poprawności politycznej lub po prostu, w zalewie testowych ćwiczeń, brakuje miejsca na kreatywność uczniów.

Do takiego mechanicznego traktowania języka Van Lier wydaje się odnosić sceptycznie:

Z jednej strony mówiąc chcemy ubarwiać i tworzyć oryginalny język, brzmieć oryginalnie i dystynktywnie, sygnalizując swoją indywidualność i przynależność do określonej grupy. Z drugiej strony użytkownicy języka (często oficjalne instytucje i szkoły) próbują ustanowić oficjalne standardy i wskaźniki „poprawnego” języka, próbując w ten sposób ograniczyć ilość wariacji języka będących w użyciu (Van Lier, 2004, s. 85 [tłum. R.S. - dot. całego artykułu]).

\section{DLACZEGO EKOLOGIA}

Spojrzenie ekologiczne, które ostatnio kojarzone jest najczęściej z ratowaniem ginącego środowiska naszej planety, stanowi w istocie sposób pojmowania zjawisk w ich całościowym kontekście lub kontekstach i nie zadowala się jedynie wyznaczeniem dwuwymiarowych linearnych wektorów charakteryzujących relacje między bardzo ograniczoną liczbą zmiennych. To z kolei odróżnia taki punkt widzenia od tradycyjnie rozumianej „metody naukowej”, która izolując zestaw wybranych składników badanego problemu, próbuje dostarczyć jego wyjaśnienie, kontrolując w sztuczny sposób obszar eksperymentu i manipulując wyselekcjonowanymi zmiennymi. Jak pisze Van Lier:

Wartość takiej metody (naukowej) nie jest kwestionowana, zważywszy na ogromny postęp nauki i technologii który miał miejsce $w$ ostatnich stuleciach. Jednakże jest równie niewątpliwe, że ten postęp jest kosztowny w odniesieniu do problemów środowiska naturalnego i pogorszenia dobrostanu ekosystemów na świecie (Van Lier, 2004, s. 4).

Autor przedstawia dwa podejścia do tego problemu, wyróżniając płytką i głęboką ekologię. Płytka ekologia polega na doraźnym usuwaniu bieżących skutków naszego 
rozwoju cywilizacyjnego, a ekologia głęboka szuka rozwiązań systemowych i łączy się $\mathrm{z}$ teorią systemów, cybernetyką, a w ostatnich latach również z teorią chaosu i złożoności. Wielu czytelników zapyta tutaj, co wspólnego ma ta tematyka z funkcjonowaniem języka i jego nauczaniem w szkole. Postaramy się na to pytanie odpowiedzieć, przywołując niektóre z dziesięciu kategorii charakteryzujących Lingwistykę Ekologiczną.

Wybrane kategorie charakteryzujące Lingwistykę Ekologiczną. We wstępie do swojej książki Van Lier składa swoistą deklarację intencji (jak sam ją nazywa) w odniesieniu do głównych koncepcji ekologii w studiowaniu i nauczaniu języka. Poniżej przedstawiamy kilka z nich wraz z komentarzem - jakkolwiek subiektywnym - ale w sposób czytelny łączącym jego koncepcje z nowoczesnymi teoriami dotyczącymi przyswajania języka i jego nauczania obecnymi już na łamach „Neodidagmaty".

Relacje. Obszarem docelowym języka są relacje wiążące jednostkę z otaczającym ją światem, język stanowi sposób na udane funkcjonowanie organizmu w środowisku. Wydaje się, że ten postulat może być najefektywniej spełniony w środowisku immersyjnym. Jak pisze Bestrzyński (2011, s. 171), „immersja jest zjawiskiem bardzo szerokim i zachodzącym na płaszczyźnie aktywności w grupie".

Kontekst. Według Van Liera, „kontekst nie jest czymś, co otacza język, lecz tak naprawdę definiuje go, będąc w tym samym czasie przez niego definiowanym" (Van Lier, 2004, s. 4). Język jest więc czymś więcej niż tylko kodem przekazującym wiadomości od A do B, nie może więc być skutecznie rozumiany, nabywany ani nauczany w oderwaniu od swojego naturalnego kontekstu. W praktyce oznacza to, że tony szkolnych zeszytów ćwiczeń do wypełniania, kupowane co roku przez uczniów, które charakteryzuje całkowite oderwanie od kontekstu społecznego, przedstawiają język we fragmentarycznej, sztucznej formie i być może jest to jedna z przyczyn ich niezmiennie niskiej atrakcyjności wśród uczniów pomimo niezmiennie wysokich kosztów zakupu.

Wyłanianie. „Lingwistyka Ekologiczna rozumie uczenie się języka nie jako stopniową, linearną akwizycję, lecz jako wyłanianie się" (Van Lier, 2004, s. 5). To zjawisko (nie proces) jest przedstawiane jako koalescencja wielu prostszych objętościowo i jakościowo elementów w systemie językowym o znacznie wyższym stopniu komplikacji. Gramatyka w takim rozumieniu nie jest czymś, czego uczymy się jako zespołu reguł i zasad, ale wyrasta wprost z użycia leksyki. Zastanawiające jest dla nas szczególnie, jak bardzo przypomina to nabywanie pierwszego języka w środowisku immersyjnym. Podobnie pisze o tej kwestii Lankiewicz: „Nikt nie uczy się słów jako haseł w słowniku, ale raczej przyswaja je z interakcji społecznej. Uczenie się całych bloków wyrazów, tak jak to proponuje podejście leksykalne, nie powinno się bardzo różnić od naturalnego uczenia się wyrażeń w języku rodzimym" (Lankiewicz, 2012, s. 216).

Jakość. Jakość w ujęciu Lingwistyki Ekologicznej, jak wyjaśnia Van Lier, odnosi się do jakości doświadczenia edukacyjnego. "Jakość doświadczenia edukacyjnego jest widziana jako zasadniczo odmienna od standardów edukacyjnych" (Van Lier, 2004, s. 5). Naszym zdaniem niezmiernie ważne jest podniesienie przemilczanej chętnie kwestii jakości doświadczenia edukacyjnego dla jego odbiorcy i emocjonalnego zabarwienia dla ucznia jego kontaktu z systemem szkolnym. Wydaje się, że mamy niewielkie prawo moralne krytykować negatywne lub trudne postawy uczniów wobec systemu szkolnego tak długo, jak konstruujemy go, widząc ucznia jako przedmiot i odmawiając przyznania wartości jego odczuciom. Harmonizuje to z wprowadzonym przez nas pojęciem nauczania responsywnego, które proponuje uczynienie z potencjałów emocjonalnych, naturalnie obecnych w uczniach, motoru edukacji zamiast budowania motywacji przez kumulację bodźców negatywnych. Tak pisze o tym Strykowska: „Ważne jest, aby na- 
uczyciel był takim pedagogiem, który może trochę wbrew ogólnej opinii wierzy, do końca w istnienie dobrej strony każdego ucznia, szczególnie tego trudnego. Jest zainteresowany światem swoich podopiecznych i stara się patrzeć na otaczające go zdarzenia z ich perspektywy" (Strykowska, 2011, s. 3).

Wartość. Autor proponuje odejście od deklarowanego powszechnie rozdziału nauki od wartości moralnych. W tym ujęciu nauczyciel wydaje się mieć obowiązek odrzucania autocenzury i łamania poprawności politycznej. Jako przykład takiego sztucznego rozszczepienia Van Lier podaje działalność naukową i polityczną Chomskiego, który nigdy nie widział związku pomiędzy tymi sferami. W praktyce szkolnej ta teoria oznacza, że nauczyciel języka nie powinien skrupulatnie pomijać tematów trudnych lub kontrowersyjnych. Owszem, nie wolno mu prowadzić indoktrynacji, ale jeśli język ma być odkrywany w swoim naturalnym kontekście, to nie możemy wykluczać z interakcji "trudnych" tematów z obawy przed krytyką rodziców czy przełożonych.

Aktywność. Jest rozumiana jako naturalne terytorium dla studiowania i uczenia się języka. Neguje się tradycyjny, skupiony na biernym, przekazującym uczniom wiedzę nauczycielu, model klasy. Van Lier proponuje w zamian „Wspólnotę opartą na praktyce, gdzie uczniowie zajmują się swoim uczeniem się poprzez aktywności różnego rodzaju, pracując parami, wspólnie lub samodzielnie" (Van Lier, 2004, s. 5). Aktywność tak rozumiana również harmonizuje z postulatami nauczania responsywnego. Podobną ideę wyraża, pisząc o immersji, Bestrzyński: „Rolą nauczyciela jest organizacja aktywności uczniów w taki sposób, aby mogło zaistnieć zjawisko przyswajania języka obcego" (Bestrzyński, 2001, s. 163).

\section{DLACZEGO SEMIOTYKA}

Semiotyka jako dziedzina wiedzy zajmująca się teorią i praktyką odczytywania, tworzenia i istnienia znaków na różnych płaszczyznach wydaje się być położona daleko od praktyki nauczania języka. Jednakże pozory, jak często się zdarza, również tym razem okazują się mylące, tym bardziej że obok lingwistyki ekologicznej stanowi ona drugi filar proponowanej przez autora filozofii języka i związanej z nią praktyki edukacyjnej.

Otóż, pojmowanie języka jako dynamicznego systemu znaków, których znaczenie jest indywidualnie i każdorazowo negocjowane oraz dodatkowo zależne od kontekstu społecznej interakcji, prowadzi w konsekwencji do ekologicznego pojmowania języka. Ta prawidłowość obowiązuje również w przeciwną stronę. Van Lier pisze o tym następująco: „Moją tezą w tej książce jest to, że ekologia i semiotyka idą ręka w rękę. To znaczy, że semiotyczne podejście do języka prowadzi do postrzegania uczenia się języka (i jego używania) z ekologicznej perspektywy. Ta z kolei prowadzi do umieszczenia uczenia się w semiotyce przestrzeni, czasu, działania percepcji i umysłu" (Van Lier, 2004, s. 55).

Dodatkowo znajdujemy tu kolejną zbieżność z proponowanymi przez nas ideami nauczania responsywnego, gdyż refleksje autora dotyczące konsekwencji semiozy (semiotycznego procesu tworzenia znaczeń) zawierają między innymi postulat, że „uczniowie to osoby, które mają coś do powiedzenia, posiadający ważne cele w życiu, a nie kolejne pozycje w statystyce, które co najwyżej wpływają na wynik testów" (Van Lier, 2004, s. 73). Jest to zbieżne z proponowaną przez nas definicją: „Nauczaniem responsywnym jest każde zachowanie i działanie nauczyciela, w którym dostraja się on do 
aktualnych potrzeb, zainteresowań i trudności ucznia, w przeciwieństwie do nauczania planowego, w którym centralne miejsce zajmuje rozkład materiału wraz z planem wynikowym" (Szymiec, 2011, s. 175).

Równie wyraźnie wyartykułowana jest kluczowa rola mechanizmów pojawiających się w immersji językowej, gdzie rola nauczyciela to bycie facylitatorem wspólnego zanurzenia w języku. Van Lier pisze o tym następująco: „Być może metodolodzy komunikacyjni przecenili pojęcie komunikacji twarzą w twarz, jako modelu interakcyjnego. Być może ważniejszy jest model angażowania wspólnej uwagi na danym zagadnieniu oparty na równorzędnej współpracy" (Van Lier, 2004, s. 73).

Jak w trakcie dyskusji seminaryjnej zauważył Bestrzyński (WSJO, listopad 2013) „niewielu edukatorów uświadamia sobie rolę semiotyki w procesie przyswajania języka, skupiając się głównie na odtwórczych aktywnościach" (które mają przygotować uczniów do testów na zakończenie semestru, roku lub szkoły). Niestety dzieje się to nie tylko kosztem zubożenia ich języka, ale również ograniczenia rozwoju ich samodzielnych strategii kognitywnych. Jest to zresztą symptomatyczne dla każdego przedmiotu humanistycznego, szczególnie gdy chodzi o język polski. Nauczyciele (oczywiście wyłącznie anonimowo) przyznają, że ich przedmiotu nie da się ani dobrze nauczać, ani oceniać umiejętności uczniów w sposób testowy. Co więcej, taki sposób orientacji (szkoły na testy) stawia uczniów kreatywnych w niekorzystnym położeniu - bo muszą się "oduczać" swojego nietypowego rozumienia i odbioru literatury, aby nauczyć się myślenia przeciętnego i przewidywalnego tylko po to, żeby potrafić „wstrzelić się” W test. Takie działanie samo $\mathrm{w}$ sobie jest $\mathrm{w}$ perspektywie semiotycznej sprzeczne $\mathrm{z}$ pojęciem języka jako kreacji. W naszym rozumieniu jest też sprzeczne $\mathrm{z}$ byciem nauczycielem perse.

\section{UWAGI KOŃCOWE}

W czasach rosnącego wpływu korporacyjnego widzenia i wartościowania świata na każdą istotną dziedzinę życia głosy niezależne od tego paradygmatu powinny być szczególnie uważnie słuchane przez wszystkich, którzy identyfikują się z ideami humanistycznymi i prospołecznymi. Mentalność korporacyjna manifestuje się uprzedmiotowieniem i manipulacyjnym traktowaniem każdego człowieka. Model edukacji masowej opartej na standardach, a nie na jakości (który to konflikt przedstawiliśmy powyżej) sprzyja ujednoliceniu myślenia uczniów i ogranicza indywidualność ich języka. Deklaratywnie każda szanująca się korporacja, podobnie jak edukacja masowa, akceptuje i wspiera różnorodność. W praktyce jednak przykłada się tę samą miarę do każdego pracownika lub ucznia, czyniąc z posłuszeństwa główną cnotę, a głosy niezależne lub krytyczne są skutecznie tłumione. Wszyscy mają wykonywać te same aktywności i udzielać tych samych, właściwych (bo zgodnych z kluczem testowym) odpowiedzi.

Być może główna wartość książki Van Liera leży w silnej teoretycznej podbudowie, którą daje ona wszystkim nieukształtowanym na wzór korporacyjny nauczycielom, wierzącym we wrodzoną kreatywność i ciekawość świata swoich uczniów i uważającym ich za coś więcej niż kolejne pozycje w dzienniku szkolnym.

Być może dzięki połączeniu pojęć ekologii oraz semiotyki w odniesieniu do języka i jego nauczania uzyskujemy unikalną perspektywę widzenia klasy jako przede wszystkim systemu i platformy interakcji społecznej. 
Być może w kategoriach humanistycznych wyeksponowanie roli ego jako indywidualnej osobowości ucznia (będącej w pełni wyrażaną i rozwijaną w kontekście społecznym), które wynika z lektury tej książki, jest odpowiedzią na dominujące tendencje w edukacji masowej, która stara się sprowadzić wszystkich jej uczestników do jednego mianownika.

Być może zamiast oceniania przez testy szkoła zezwoli na twórcze oceniania prac uczniów poprzez ich własnych nauczycieli według innych kryteriów niż przeliczniki punktów. Uczniowie doskonale widzą brak zaufania, jeśli nie wręcz podejrzenie o nieczyste intencje nauczyciela leżące u podstaw anonimowego sprawdzania prac testowych przez obcych nauczycieli.

Być może. Tymczasem polecamy lekturę tej książki wszystkim, którzy podejrzewają, że nabywanie kompetencji językowej nie ma wiele wspólnego z uczeniem się na pamięć niekończących się list słownictwa i wybieraniem z listy odpowiedzi z pozycji A, B lub C. Głównie jednak polecamy ją nauczycielom - również polonistom, gdyż połączenie semiotyki i ekologii może zmienić sposób, w jaki „nauczamy” również języka rodzimego tak, aby promować kreatywność i niezależne myślenie, nawet jeśli jest to sprzeczne z panującym korporacyjnym paradygmatem.

W naszej recenzji świadomie porzuciliśmy sztampowe przedstawienie książki jako zbioru następujących po sobie uwag merytorycznych lub organizacyjnych dotyczących kolejnych jej rozdziałów. Staraliśmy się zamiast tego podążać za myślą przewodnią autora i przyglądać się jej z naszej immersyjno-responsywnej perspektywy. Dodatkowo chcieliśmy zwrócić uwagę na interdyscyplinarny charakter tej publikacji oraz przedstawić, jak można ją odczytać w kontekście problemów edukacji masowej. Chcielibyśmy wreszcie tą drogą podkreślić, że dopiero dwa lata temu ukazało się tłumaczenie tej publikacji na język japoński i może dobrze byłoby postarać się o polskie jej tłumaczenie, aby można ją było włączyć do lektur wielu kierunków pedagogicznych i humanistycznych.

\section{LITERATURA}

Bestrzyński W., Immersja językowa, „Neodidagmata” 2011, 31/32.

Lankiewicz H., From life to text: Building linguistic and cultural identity, Państwowa Wyższa Szkoła Zawodowa w Pile, Piła 2012.

Strykowska J., Monografia naukowa XVII Tatrzańskiego Sympozjum Naukowego, „Edukacja jutra", Wyd. Wyższa Szkoła Humanitas, Zakopane 2011.

Szymiec R., Nauczanie responsywne i jego cechy konstytutywne, "Neodidagmata” 2011, $31 / 32$. 